\title{
Intention to Pursue Overseas Jobs among University Students and Graduates: A Case Study from University of Peradeniya, Sri Lanka
}

\author{
C.A.K. Weerasinghe ${ }^{*}$ and S. Kumar ${ }^{1}$ \\ Postgraduate Institute of Agriculture \\ University of Peradeniya \\ Sri Lanka
}

\begin{abstract}
Sri Lanka is experiencing migration of skilled workers, which has been on the increase over the years. Graduates are one of the most valuable skilled worker groups that Sri Lanka produces and it is clear that some of them are leaving the country to secure employment overseas. Yet it is unclear why these individuals leave or whether their decision to leave is consistent with their objectives while at the university. This paper used the theory of planned behaviour (TPB) to understand the behavioural intention to pursue overseas employment by identifying the relevant antecedent factors and assessing whether the actual behaviour is facilitated by the perceived behaviour towards overseas jobs. The study involved collection of data from 200 undergraduates of, and 397 graduates (201 migrated graduates, 196 graduates in Sri Lanka) who graduated from the University of Peradeniya, Sri Lanka. Data were analyzed using the hierarchical multiple regression analysis and hierarchical logistic regression analysis. Findings showed that the attitudes and self-efficacy fully contributed while the subjective norms partially contributed to the prediction of behavioural intention towards an overseas career. Both perceived behavioural control and behavioural intention had contributed to predict the actual behaviour.
\end{abstract}

Keyword: Graduates' behavioural intention, overseas job intention, career planning of university students

\section{INTRODUCTION}

Choosing career alternatives outside Sri Lanka is becoming increasingly common among the skilled workers (DCS, 2010). Graduates are a major category of skilled migrants (Carrington and Detragiache, 1998; Adams, 2003; Docquier and Marfouk, 2004, 2006; Dumont and Lemaitre, 2004) and have attracted considerable attention in this context (Faggian et al. 2006, 2007a, b; Faggian and McCann, 2009; Bond et al., 2008) in the recent years. One manner in which attention has been drawn to graduates is in terms of their competitiveness in the global job market.

The International Organization for Migration (IOM, 2010) identifies Sri Lanka as having a large mismatch between the international demand for jobs and its capability to address these demands. Sri Lankan labour migration is concentrated on low-skilled labour categories (MFEPW, 2013). The Sri Lanka Bureau of Foreign Employment (SLBFE, 2011) reported that the global demand for skilled workers was 252,430 in 2010 . The skilled workers from Sri Lanka filled 28 percent of this demand. While not all skilled workers may necessarily be

1 Department of Agricultural Economics and Business Management, Faculty of Agriculture, University of Peradeniya, Peradeniya, Sri Lanka

Corresponding author: asawee999@gmail.com 
graduates, the latter may constitute a significant portion of skilled workers and would represent a segment of the population that may be able to fill these positions. The University Grants Commission (UGC, 2011) reported that the graduate output from all the government universities in 2010 was 12,346 . Considering the current concern over the employability of graduates (Mahinda Chinthana, 2005), understanding their interest in pursuing such positions will be useful.

From the perspective of the government and its concern over foreign revenue, Sri Lanka depends largely on remittances. In the year 2012, remittances were around 9 percent of the GDP (CBSL, 2013), which is a significant contribution. In addition, the SLBFE (2011) highlights the fact that the earnings from skilled jobs are much higher than semi-skilled and unskilled jobs. Hence, the GDP from remittances could be increased with the increase in overseas employment of skilled workers from Sri Lanka.

\section{Conceptual framework of the Study}

Although, skilled migration/ brain drain has attracted considerable attention of many researchers (e.g. Bhagwati and Hamada, 1974; Bhagawati and Wilson, 1989; Wickramasekara, 2002; Commander et al., 2004; Schiff, 2005; Docquier et al., 2007) with respect to losses and benefits for the donor country, it is difficult to find research on the determinants behind the migrant's intentions and perception on choosing a foreign posting as a career option. Thus, this study aimed at investigating the determinants that facilitate Sri Lankan university students' and graduates' persuasion towards seeking overseas jobs and to identify whether the actual behaviour is facilitated by the perceived behaviour toward overseas jobs.

Theory of Planned Behaviour - TPB (Ajzen, 1991) has been successfully used to explain the behaviour across a wide variety of contexts (Lin et al., 1999). According to the TPB, intention to perform a behaviour is a consequence of one's attitude, subjective norm and perceived behavioural control. Attitude refers to an individual's judgment of an object (Fishbein and Ajzen, 1975), subjective norms are the perceived social pressures to perform or not the behaviour, and perceived behavioural control is the perceived ease or difficulty of performing a behaviour of interest (Ajzen, 1991).The behavioural intention and perceived behavioural control affect the actual behaviour (Fig 1). 


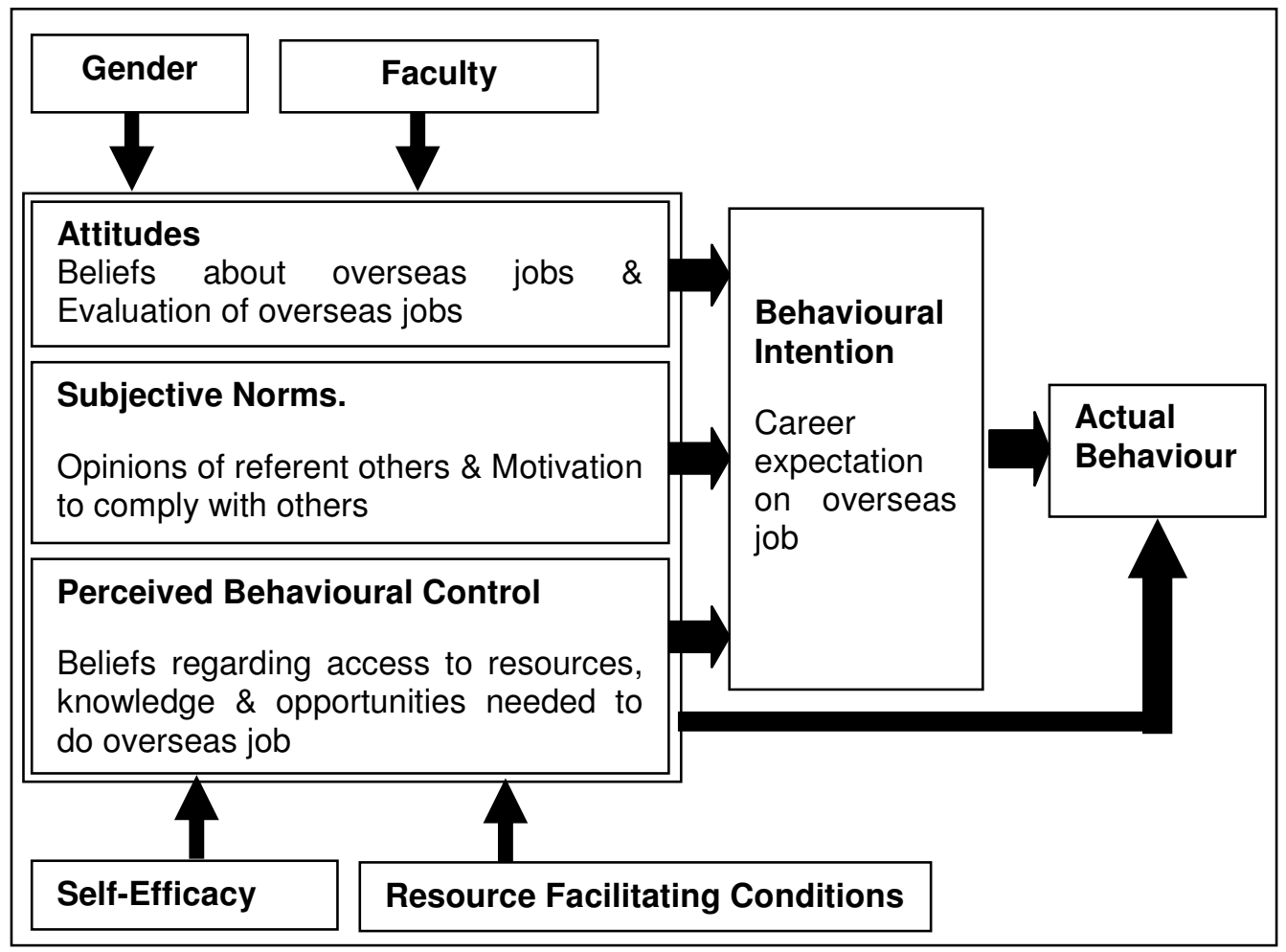

Fig. 1. Conceptual framework

The model proposed by Taylor and Todd (1995) and Morris and Dillon (1997) provides support to the idea that attitudes exert effect on behavioural intention. Hence, the associated hypotheses in this study were,

H1 : Attitudes towards overseas jobs will positively affect individual's behavioural intention to do overseas jobs.

$\mathrm{H} 2$ : There is a significant relationship between subjective norms and behavioural intention towards overseas jobs.

H3: There is a significant relationship between perceived behavioural control and behavioural intention towards overseas jobs.

According to Ajzen $(1985,1991)$, the perceived behavioural control is made up of selfefficacy and resource facilitating condition. Resource facilitating condition reflects the availability of resources needed to engage in a behaviour such as time, money or other specialized resources. Self-efficacy refers to individuals' belief in their capacity to accomplish a job or set of tasks (Bandura et al., 1977). Thus, the related hypothesis for this study were;

H4: There is a relationship between resource facilitating condition and behavioural intention toward overseas jobs.

H5: There is a relationship between self-efficacy and behavioural intention toward overseas jobs. 
The concept of TPB was based on the idea that behavioural achievement depends on behavioural intention and perceived behavioural control (Ajzen, 1985; 1989). Hence, the associated hypothesis for this study were;

H6: Behavioural intention toward overseas jobs will positively affect the individual's behaviour to do an overseas job

H7: Perceived behavioural control toward overseas jobs will positively affect the individual's behaviour to do an overseas job

Further, gender and Faculties of study in the University were used as control variables.

\section{RESEARCH DESIGN AND METHODOLOGY}

\section{Instrument development}

Development of the scales to measure each of the constructs in the model proceeded through a series of steps. As the first step, items to measure behavioural intention, attitudes, subjective norm and perceived behavioural control were generated based on a questionnaire used by Taylor and Todd (1995), Limayem et al. (2000), Kwong and Lee (2002) and Wang and Liu (2009). Facilitating condition and self-efficacy items were generated based on the model developed by Taylor and Todd (1995). All the above responses were scored on a seven-point rating scale ranging from strongly disagree (1) to strongly agree (7).

Initial items to measure each construct were identified based on the scales as described above. Discussions were held by the authors with the third and final year students and graduates to ensure that the items were consistent with the actual context. On the basis of the results of the above procedure, some items were modified, inserted or deleted. Questions asked of all participants were the same. However, those who were based in other countries were given the questions in the past tense and all others were given in the future tense.

\section{Sample}

It was assumed that once undergraduates select fields of specialization, they should have made an initial decision regarding the occupational choice. Many still may have only a vague idea about their post-graduation plans, however, by the third year of the academic work, the students are likely to have a better understanding of their options regarding their careers. Hence, 200 undergraduates from the third year onward of the University of Peradeniya, Sri Lanka were selected for this study. Students represented all 8 faculties with the percentages of 11, 15, 4, 4, 9, 16, 6 and 35 from Faculties of Medical, Engineering, Dental, Veterinary, Agriculture, Science, Allied Health Science and Arts, respectively. Proportional quota sampling method was used to select participants as using a probability sampling method was found to be impractical. In addition, 201 migrated graduates and 196 non-migrated graduates of the University of Peradeniya participated in the study. For alumni, a snow ball sampling method was used as a sampling frame was unavailable.

\section{Data collection}

The researchers collected data from the University students during a period of 2 months. Participants took approximately $10-15$ minutes to complete the questionnaire. The data were collected from graduates through a self-administered web-based questionnaire, which was 
designed in a way to preserve the anonymity of the respondents. All respondents were informed that the data were collected as part of a University research study. To avoid demand effects, the respondents were guaranteed that all answers would be anonymous.

\section{Measurement instruments}

Prior to a full scale study, a pilot test was conducted with 15 respondents. For the assessment of the pilot test, Cronbach's alpha coefficient was calculated. Nunnally (1967) argued that in the early stages of research, reliabilities ranging from 0.50 to 0.60 would suffice and for basic research, beyond 0.80 is not necessary. Hence for this research, an alpha level of 0.70 was considered as an indication of acceptable reliability. For all scales, the alpha coefficient was closer to 1 (Table1).

Table 1. Cronbach's alpha values of scales

\begin{tabular}{lc}
\hline Scale & Cronbach's alpha \\
\hline Behavioural intention & 0.926 \\
Attitudes & 0.924 \\
Subjective norm & 0.891 \\
Perceived behavioural control & 0.811 \\
Facilitating condition & 0.850 \\
Self-efficacy & 0.836 \\
\hline
\end{tabular}

The final questionnaire contained 37 questions to measure the constructs of interest as well as some demographic and other related questions. Principal Component Analysis (PCA) was conducted on the determinants of behavioural intention. The components that emerged with eiganvalues greater than one were used. Table 2 gives the factor loadings, which were consistent with the expected model.

Table 2. Factor loadings of principal component analysis

\begin{tabular}{lccc}
\hline & \multicolumn{3}{c}{ Component } \\
\cline { 2 - 4 } Item & Attitude & $\begin{array}{c}\text { Subjective } \\
\text { Norm }\end{array}$ & $\begin{array}{c}\text { Perceived } \\
\text { Behavioural } \\
\text { Control }\end{array}$ \\
\hline Attitude 1 & 0.826 & 0.185 & 0.132 \\
Attitude 2 & 0.824 & 0.132 & 0.140 \\
Attitude 3 & 0.824 & 0.178 & 0.136 \\
Attitude 4 & 0.793 & 0.076 & 0.242 \\
Attitude 5 & 0.852 & 0.194 & 0.080 \\
Attitude 6 & 0.703 & 0.243 & 0.356 \\
Attitude 7 & 0.719 & 0.339 & 0.235 \\
Attitude 8 & 0.790 & 0.234 & 0.250 \\
Attitude 9 & 0.791 & 0.296 & 0.180 \\
Subjective Norm 1 & 0.236 & 0.845 & 0.072 \\
Subjective Norm 2 & 0.267 & 0.882 & 0.095 \\
Subjective Norm 3 & 0.220 & 0.854 & 0.187 \\
Perceived Behavioural Control 1 & 0.303 & 0.062 & 0.788 \\
Perceived Behavioural Control 2 & 0.118 & 0.220 & 0.812 \\
Perceived Behavioural Control 3 & 0.215 & 0.053 & 0.856 \\
\hline
\end{tabular}




\section{Statistical methods}

In this study, the hierarchical multiple regression analysis was used to test the first primary objective i.e. to identify the determinants of persuasion of university students and graduates towards overseas jobs, and was conducted separately for undergraduate and graduates. The regression model used the behavioural intention as the dependent variable. Behavioural intention was normally distributed according to Pallant (2005) i.e. for the sample of undergraduates, the Kolmogorov Smirnov value was 0.2, skewness was -0.259 and kurtosis was -0.253 , while for the sample of graduates, the Kolmogorov Smirnov value was 0.097, skewness was -0.039 and kurtosis was -0.619 . To evaluate the second primary objective on the role of behavioural intention and perceived behavioural control on actual behaviour (i.e. migrated or not migrated) the composite of non-migrated and migrated graduates' samples was analyzed. A logistic regression analysis was conducted with their place of work (Sri Lanka, away from Sri Lanka), as the dependent variable and behavioural intention and perceived behavioural control as the independent variable. As the behavioural intention to obtain overseas jobs is only relevant to those present in Sri Lanka, these hypotheses were tested only for undergraduates and graduates of the University of Peradeniya who are residing in Sri Lanka.

\section{RESULTS AND DISCUSSION}

\section{Descriptive statistics}

The descriptive analysis of the formal variables Showed that the undergraduates had stronger behavioural intention toward overseas jobs compared to the graduates of University of Peradeniya who are currently in Sri Lanka and abroad (Table 3)

\section{Table 3. Descriptive statistics}

\begin{tabular}{lcccccc}
\hline & \multicolumn{2}{c}{ Undergraduates } & \multicolumn{2}{c}{$\begin{array}{c}\text { Graduates in } \\
\text { Sri Lanka }\end{array}$} & \multicolumn{2}{c}{ Graduates abroad* } \\
\cline { 2 - 7 } Scale & Mean & $\begin{array}{c}\text { Std. } \\
\text { Deviatio } \\
\text { n }\end{array}$ & Mean & $\begin{array}{c}\text { Std. } \\
\text { Deviatio } \\
\text { n }\end{array}$ & Mean & $\begin{array}{c}\text { Std. } \\
\text { Deviatio } \\
\text { n }\end{array}$ \\
\hline $\begin{array}{l}\text { Behavioural } \\
\text { Intention }\end{array}$ & 4.88 & 1.33 & 3.86 & 1.25 & 4.04 & 1.43 \\
$\begin{array}{l}\text { Attitude } \\
\begin{array}{l}\text { Subjective } \\
\text { Norm }\end{array}\end{array}$ & 4.87 & 1.41 & 4.38 & 1.40 & 4.60 & 1.43 \\
$\begin{array}{l}\text { Perceived } \\
\text { Behavioural }\end{array}$ & 4.02 & 1.52 & 3.97 & 1.55 & 4.08 & 1.90 \\
$\begin{array}{l}\text { Control } \\
\text { Resource }\end{array}$ & 4.87 & 1.37 & 4.60 & 1.33 & 5.43 & 1.15 \\
$\begin{array}{l}\text { Facilitating } \\
\begin{array}{l}\text { Condition } \\
\text { Self-Efficacy }\end{array}\end{array}$ & 3.58 & 1.07 & 3.93 & 1.10 & 5.06 & 1.03 \\
\hline $\begin{array}{l}\text { Note. For graduates abroad, this questionnaire was formed with respect to their experience while in Sri Lanka (prior } \\
\text { to going abroad) }\end{array}$ & & & & & & \\
\end{tabular}




\section{Hypothesis testing}

Hypotheses 1 to 5 tested the relationships between determinants and behavioural intention. The results revealed a significant model (Tables 4 and 5).

Table 4 Explicability of the model: Hierarchical multiple regression

\begin{tabular}{lcc}
\hline Details & Undergraduates & Graduates \\
\hline Df & 7 & 7 \\
F statistic & $36.743^{*}$ & $56.661^{*}$ \\
$\mathrm{R}^{2}$ & $0.652^{*}$ & $0.599 *$ \\
\hline$p<0.05$ & &
\end{tabular}

Table 5. Regression coefficients for predicting behavioural intention

\begin{tabular}{lcc}
\hline Independent/Latent variable & Undergraduates & $\begin{array}{c}\text { Graduates residing in Sri } \\
\text { Lanka }\end{array}$ \\
\cline { 2 - 3 } & Beta & Beta \\
\hline Faculty & 0.08 & 0.05 \\
Gender & -0.04 & 0.02 \\
Attitudes & $0.23^{* *}$ & $0.58^{* * *}$ \\
Subjective norm & $0.16^{* *}$ & 0.03 \\
Perceived behavioural control & -0.04 & -0.11 \\
Resource facilitating condition & -0.02 & -0.02 \\
Self-Efficacy & $0.62^{* * *}$ & $0.32^{* * *}$ \\
\hline
\end{tabular}

Note. ${ }^{*} p<0.05 . \quad * * p<0.01 . \quad * * * p<0.001$

As the TPB reflects, in this study, the attitudes had a significant positive relationship with the behavioural intention for both groups and the results are consistent with the findings of Armitage et al.(1999),Davis et al.(2002) and Kwong and Lee (2002). The model revealed a significant relationship between subjective norms and behavioural intention for the undergraduate sample but not for the graduate sample present in Sri Lanka. Thus, there is a partial support for Hypothesis 2. Kwong and Lee (2002) and Reinecke et al. (1996) demonstrated a strong effect of subjective norms for youth indicating a strong influence of outside pressure on the behaviour of youth. In Sri Lanka, undergraduates are more dependent and people around them dream about their bright future. After graduation this situation changes with time. This might be the reason for such observation.

Resource facilitating condition and perceived behavioural control was important in predicting only the actual behaviour rather than the intentions of those who are still living in Sri Lanka. These two factors have thus, significantly distinguished graduates who remain in the country compared to those who have left, and many suggests that they are the decisive factor in whether graduates are practically able to pursue overseas work. This possibility makes sense as both, resource facilitating condition and perceived behavioural control depend on the context in which these graduates find themselves. These findings are inconsistent with the findings reported by Kwong and Lee (2002). At the present in Sri Lanka, there are many agents who facilitate almost all the requirements on behalf of migrators, and the services are available for an affordable price and hence, the graduates 
need not have much concern on the availability of resources such as time, help from others and finances.

Findings related to testing of Hypothesis 5 predicted that the self-efficacy towards getting overseas jobs was significantly related with the behavioural intention and the results were consistent with those of Hung et al. (2003) and George (2004). This expresses the judgments of their capabilities to get an overseas job is somewhat certain as they have the required capabilities and qualifications. However, further research should explore these possibilities further.

As illustrated in Fig 2, both the behavioural intention and perceived behavioural control showed a significant and positive relationship with behaviour. This shows that when the intention and perceived easiness are more towards securing an overseas job, there is a higher possibility to get it. These findings are in accordance with the results of Davis et al. (2002).

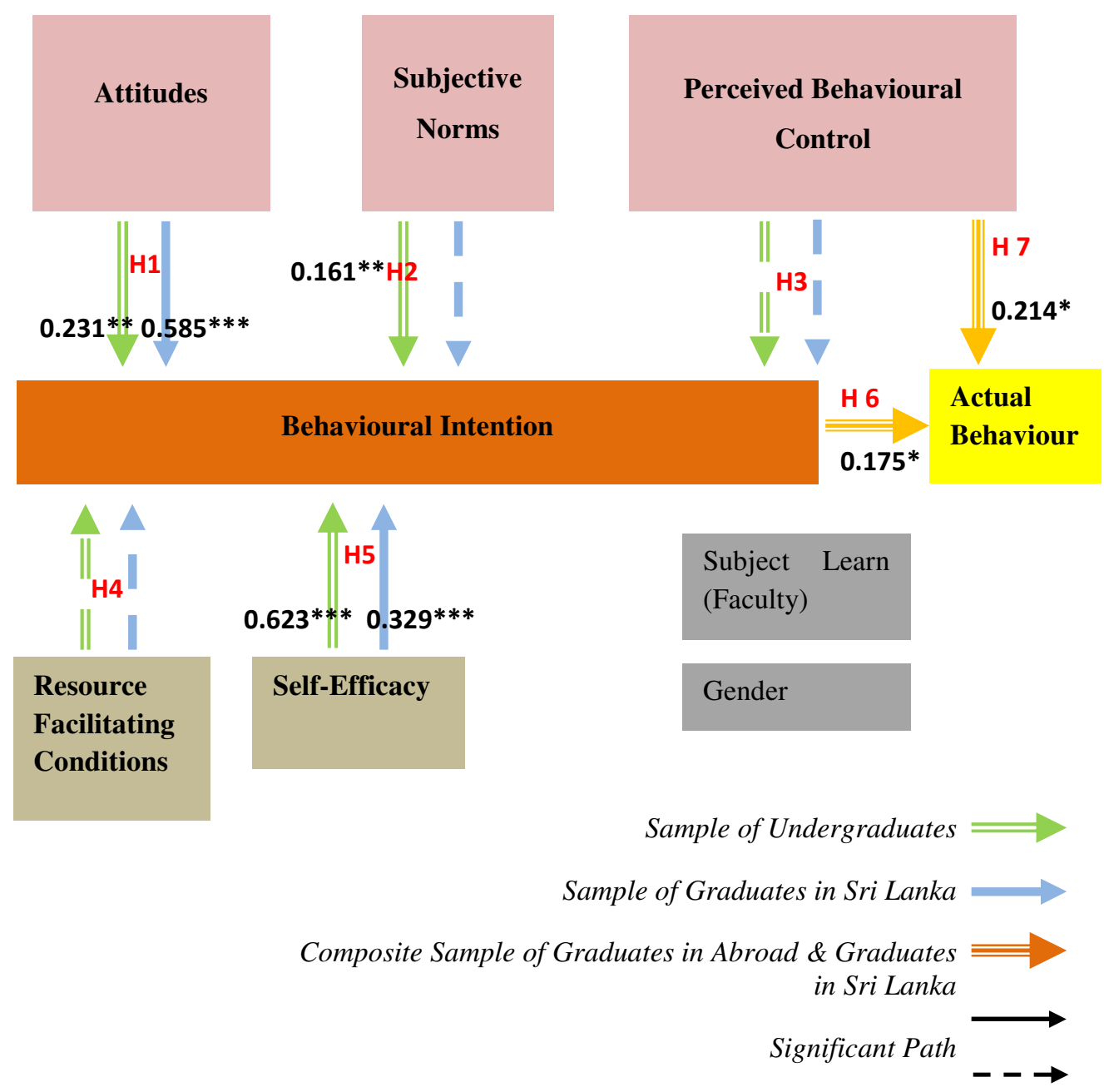


Fig. 2. Graphical representations of the hypotheses testing (Note. $* p<.05 . \quad * * p<.01$. $* * * p<.001)$

The model correctly classified 78.1 percent of cases overall Table 6 accurately picked that 77.1 percent of them have migrated. The specificity of the model is the percentage of the group without the characteristic of interest (not migrated) that is correctly identified (true negatives). Here, the specificity is 79.1 percent (graduates did not migrate were correctly predicted as not to migrate by the model).

Table 6. Model's predicting ability: Logistic regression analysis

\begin{tabular}{llccc}
\hline Observed & & \multicolumn{3}{c}{ Predicted } \\
\cline { 3 - 4 } & & \multicolumn{2}{c}{ Behaviour } & Percentage \\
\cline { 3 - 4 } & & Not Migrated & Migrated & Correct \\
\hline Behaviour & Not migrated & 155 & 41 & 79.1 \\
& Migrated & 46 & 155 & 77.1 \\
& Overall & & & 78.1 \\
\hline
\end{tabular}

Table 7 indicates that other than the subjective norm, all the other determinants have contributed to the prediction of actual behaviour.

Table 7. Logistic regression results for predicting migration

\begin{tabular}{lccc}
\hline Determinant & B value & Sig & Exp (B) \\
\hline Behavioural intention & 0.175 & 0.024 & 0.667 \\
Perceived behavioural control & 0.214 & 0.025 & 0.911 \\
Attitudes & 0.092 & 0.023 & 1.278 \\
Subjective norm & 0.016 & 0.062 & 1.016 \\
Resource facilitating condition & 0.841 & 0.000 & 1.181 \\
Self-efficacy & 0.298 & 0.035 & 1.231 \\
\hline
\end{tabular}

\section{CONCLUSION}

The study examined two dependent variables; intention to pursue oversees work and actual behaviour. The results indicated that both self-efficacy and attitudes predicted the intentions as well as actual behaviour. The results were less consistent for subjective norms, perceived behavioural control and resource facilitating condition. The subjective norms significantly predicted only the intention of undergraduates to pursue such overseas careers and may reflect the unique cohesion that university students have with each other, which provides a strong determinant to their attitudes. Resource facilitating condition and perceived behavioural control did not contribute to the prediction of behavioural intention in undergraduates and graduates in Sri Lanka though it contributed to predict the actual behaviour. Hence, further research should explore the reason.

The present study was done in a limited scope in terms of its sampling technique, which used non-probabilistic method due to practical difficulties in data collection. The study also did not examine the types of jobs that graduates were pursuing overseas. Hence, further research should address these concerns as well as this might provide a more nuanced understanding on the issue. 


\section{REFERENCES}

Adams, R. (2003). International migration, remittances and the brain drain: a study of 24 labor-exporting countries. World Bank Policy Research Working Paper No. 2972. Ajzen, I. (1991). The theory of planned behaviour. Organizational Behaviour and Human Decision Processes. 50, 179 - 211.

Ajzen, I. (1989). Attitude Structure and Behaviour. In: Breckler, S.J. and Greenwald, A.G. (Ed.) Attitude Structure and Function. Lawrence Erlbaum Associates, Hillsdale.

Ajzen, I. (1985). From Intentions to Actins: A theory of Planned Behaviour. In: Kuhl, J. and Bechmann, J. (Ed.) Action-Control: From Cognition to Behaviour. Springer, Heidelberg.

Armitage, C.J., Conner, M., Loach, J. and Willetts, D. (1999). Different perceptions of control: Applying an extended theory of planned behaviour to legal and illegal drug use. Basi and applied social psychology. 21(4), $301-316$.

Bandura, A., Adams, N.E. and Beyer, J. (1977). Cognitive processes mediating behavioural change. Journal of Personality and Social Psychology. 35, 125 - 139.

Bhagwati, J.N. and Hamada, K. (1974). The brain drain, international integration of markets for professionals and unemployment: A Theoretical Analysis. Journal of Development Economics. V1, n1, 19 - 42.

Bhagwati, J.N. and Wilson, J.D. (1989). Income Taxation and International Mobility. MA: M.I.T. Press, Cambridge.

Bond, R., Charsley, K. and Grundy, S. (2008). Scottish Graduate Migration and Retention: a case study of the University of Edinburgh 2000 cohort. Scottish Affairs. 63, 17 - 43.

Carrington, W.J. and Detragiache, E. (1998).How big is the brain drain?. IMF Working paper WP/98/102.

Central Bank of Sri Lanka (2013). Annual Report 2012. Central Bank of Sri Lanka, Colombo, Sri Lanka.

Commander, S., Kangasniemi, M. and Winters, L.A. (2004). The brain drain: a review of theory and facts. Brussels Economic Review. 47(1), 29 - 44.

Davis, L.E., Ajzen, I., Saunders, J. and Williams, T. (2002). The decision of African American students to complete high school: an application of the theory of planned behaviour. Journal of Educational Psychology. 94(4), 810 - 819.

DCS (2010). Statistical Abstract. Department of Census and Statistics, Colombo, Sri Lanka.

Docquier, F.and Marfouk, A. (2004). Measuring the international mobility of skilled workers (1990-2000).World Bank Policy Research Working Paper. No 3381, August. 
Docquier, F. and Marfouk, A. (2006). International migration by educational attainment (1990-2000), In: Ozden, C. and Schiff, M. (Ed.) International migration, remittances and the brain drain. Palgrave, Macmillan.

Docquier, F., Lohest, O. and Marfouk, A. (2007).Brain Drain in Developing Countries. Discussion Paper.

Dumont, J.C. and Lemaître, G. (2004). Counting immigrants and expatriates in OECD countries: a new perspective. Mimeo, OECD.

Faggian, A., McCann, P., and Sheppard, S.C. (2006). An Analysis of Ethnic Differences in UK Graduate Migration. Annals of Regional Science. 40(2), 461 - 471.

Faggian. A., McCann, P. and Sheppard, S.C.(2007a). Some evidence that women are more mobile than men: gender differences in UK graduate migration behaviour. Journal of Regional Science. 47(3), 517 - 539.

Faggian.A., McCann, P. and Sheppard, S.C. (2007b). Human Capital, Higher Education and Graduate Migration: An Analysis of Scottish and Welsh Students. Urban Studies. 44, 2511 2528.

Faggian, A., and McCann, P. (2009). Human capital, graduate migration and innovation in British regions. Cambridge Journal of Economics, 33(2), 317 - 333.

Fishbein, M. and Ajzen, I. (1975). Belief, attitude, intention, and behaviour: An introduction to theory and research. Reading, MA: Addison-Wesley.

George, I.F. (2004). The theory of planned behaviour and internet purchasing. Internet research. (14), $198-212$.

Hung, S.Y., Ku, C.Y. and Chang, C.M. (2003). Critical factors of WAP services adoption: An empirical study. Electronic commerce research and applications. 2(1), 42 - 60.

IOM (2010). World Migration Report. International Organization for Migration, Colombo, Sri Lanka.

Kwong, T.C.H. and Lee, M.K.O. (2002). Behavioural Intention Model for the Exchange Mode Internet Music Piracy. Proceedings of the $35^{\text {th }}$ Hawaii International Conference on System Sciences-2002, New York, McGraw-Hill, 1-9.

Limayem, M., Khalifa, M. and Frini, A. (2000). What makes Consumers buy from Internet? A Longitudinal study of Online Shopping: IEEE Transactions on Systems, Man and Cybernetics - Part A. Systems and Human. 30(4), 421 - 432.

Lin, T.C., Hsu, M.H., Kuo, F.Y. and Sun, P.C. (1999). An Intention Model-based Study of software Piracy. In: Sprague, R.H. (Ed.) Proceedings of the $32^{\text {nd }}$ Hawaii International Conference on System Sciences. IEEE Computer Society Press: New York, USA.

MFEPW (2013). Migration Profile Sri Lanka. Ministry of Foreign Employment Promotion and Welfare, Government of Sri Lanka. Karunarathne and Sons, Colombo, Sri Lanka. 
Morris, M.G. and Dillon, A. (1997). How user perceptions influence software use. IEEE Software. 14(4), 58 - 65.

Nunnally, J.C. (1967). Psychometric Theory. McGraw Hill, New York, USA.

Pallant, J. (2005). SPSS Survival Manual. Ligare, Sydney, Australia.

Rajapaksha, M. (2005). Mahinda Chinthana. Print and Print Graphics, Colombo, Sri Lanka.

Reinecke, J., Schmidt, P., and Ajzen, I. (1996). Application of the theory of planned behaviour to adolescents' condom use: A panel study 1. Journal of applied social psychology, 26(9), 749 - 772.

Schiff, M. (2005). Brain Gain: Claims about its size and impact on welfare and growth are greatly exaggerated. IZA Discussion Paper. n. 1599. Bonn.

SLBFE (2011). Annual statistical report of foreign employment. Sri Lanka Bureau of Foreign Employment, Colombo, Sri Lanka.

Taylor, S.A. and Todd, P.A. (1995). Understanding information technology usage: A test of competing Models. Information Systems Research. 6(2), 144 - 176.

UGC (2011). Sri Lanka University Statistics 2010, University Grants Commission, Sri Lanka[online]. [Accessed on 02.12.2013]. Available at http://www. ugc.ac.lk/en/publications/1115-sri-lanka-university-statistics-2010-.html

Wang, W.H. and Liu, Y.J. (2009). "Attitude, Behavioural Intention and Usage: An Empirical Study of Taiwan Railway's Internet Ticketing System." South West Decision Sciences Institute 2009 Proceedings, 25-28.

Wickramasekara, P. (2002). Asian labour migration: Issues and challengers in the era of globalization. International Migration Papers. 57, International Labour Office (ILO), Geneva. 


\section{APPENDIX 1 - Measurement of instruments}

\begin{tabular}{|c|c|}
\hline No. & Item \\
\hline \multicolumn{2}{|c|}{ Attitude } \\
\hline 1 & Doing an overseas job is a good idea \\
\hline 2 & Doing an overseas job is a wise idea \\
\hline 3 & I like the idea of doing an overseas job \\
\hline 4 & Doing an overseas job is beneficial \\
\hline 5 & Doing an overseas job is valuable \\
\hline 6 & Doing an overseas job would be pleasant \\
\hline 7 & Doing an overseas job will make me feel happy \\
\hline 8 & Doing an overseas job will make me feel positive \\
\hline 9 & Doing an overseas job will make me feel good \\
\hline \multicolumn{2}{|c|}{ Subjective Norm } \\
\hline 1 & People who influence my behaviour/ decisions would think that I should do an overseas job \\
\hline 2 & People who are important to me would think that I should do an overseas job \\
\hline 3 & People whom I respect would expect me to do an overseas job \\
\hline \multicolumn{2}{|r|}{ Perceived Behavioural Control } \\
\hline 1 & I would be able to do an overseas job \\
\hline 2 & Doing an overseas job is entirely within my control \\
\hline 3 & I have the resources and the knowledge and the ability to do an overseas job \\
\hline \multicolumn{2}{|r|}{ Behavioural Intention } \\
\hline 1 & I intend to do an overseas job in the near future(i.e. soon after graduation) \\
\hline 2 & I expect to do an overseas job in the near future (i.e. soon after graduation) \\
\hline 3 & It is likely that I will try to do an overseas job in the near future \\
\hline 4 & I predict that I will do an overseas job in the future \\
\hline 5 & $\begin{array}{l}\text { Although I will likely do an overseas job, I think that I may not do an overseas job but have a job } \\
\text { in Sri Lanka in the future }\end{array}$ \\
\hline 6 & I expect that I will do an overseas job \\
\hline \multicolumn{2}{|r|}{ Self Efficacy } \\
\hline 1 & I would feel comfortable pursuing an overseas job on my own \\
\hline 2 & For me, feeling comfortable pursuing an overseas job on my own is important \\
\hline 3 & If I wanted to, I could easily pursue an overseas job on my own \\
\hline 4 & For me, being able to easily pursue an overseas job on my own is important \\
\hline 5 & $\begin{array}{l}\text { I would be able to pursue an overseas job even if there was no one around to guide me how to do } \\
\text { it }\end{array}$ \\
\hline 6 & $\begin{array}{l}\text { For me, being able to pursue an overseas job even if there was no one around to guide me how to } \\
\text { do it, is important }\end{array}$ \\
\hline \multicolumn{2}{|r|}{ Resource Facilitating Condition } \\
\hline 1 & Pursue an overseas job will be too expensive. \\
\hline 2 & For me, being able to pursue an overseas job for a low cost is important \\
\hline 3 & I won't be able to get relevant information when I need it \\
\hline 4 & For me, being able to get relevant information when I need it is important \\
\hline 5 & There will not be satisfactory advisory service for me to facilitate migrating \\
\hline 6 & For me, having satisfactory advisory service for migrating is important \\
\hline 7 & There will not be enough working experience for me to facilitate migrating \\
\hline 8 & For me, having enough working experience for migrating is important \\
\hline 9 & There will not be relatives/ friends for me in target country to facilitate migrating \\
\hline 10 & For me, having relatives/ friends in target country for migrating is important \\
\hline
\end{tabular}

